\title{
INDEKS PENULIS
}

Seluruh penulis yang artikel ilmiahnya diterbitkan di Jurnal Sains Komunikasi dan Pengembangan Masyarakat dituliskan pada daftar berikut yang diurut secara abjad dilengkapi dengan halaman artikel.

Afriliyeni

433-449

Anna Fatchiya

$462-472$

Arya Hadi Dharmawan

390-407

Dinda Karunia Putri

408-417

Fredian Tonny Nasdian

360-372

Huky Arvi Loany

373-389

Iqbal Rahmat Gani

390-407

Irza Farabi Wibowo

418-432

Martua Sihaholo

433-449

Murdianto

345-359

Murdianto

373-389

Ninuk Purnaningsih

408-417

Nuraini W. Prasodjo

450-461

Pudji Muljono

418-432

Rai Sita

433-449

Randi Firman Syah

345-359

Ratu Monita Citra Pratiwi

462-472

Sri Devi Wahyuni

450-461

Vifian Rasyadi

360-372 


\section{INDEKS SUBJEK}

Alih Fungsi Lahan

462-472

CSR

373-389

Efektivitas

345-359

Efektivitas

373-389

Fungsi Pekarangan

450-461

Informasi Pertanian

418-432

Keberdayaan

373-389

Keikutsertaan

360-372

Kelompok Tani

418-432

Kerentanan Nafkah

390-407

Kesejahteraan

360-372

Kesejahteraan

433-449

Konflik Agraria

345-359

Lahan

433-449

Media Komunikasi

418-432

Model Kampung

345-359

Konservasi

360-372

Pariwisata

450-461

Pekarangan

408-417

Pemberdayaan Perempuan

462-472

Pertanian

462-472

Reforma Agraria

433-449

Rumah Tangga

450-461

Rumah Tangga Nelayan

390-407

Sekolah Ibu

408-417

Sikap

462-472

Strategi Nafkah

390-407 


\section{UCAPAN TERIMA KASIH}

Ucapan terima kasih dan penghargaan sebesar-besarnya kami sampaikan kepada para Editor yang telah berkontribusi memberikan masukan kepada para penulis untuk pengayaan substansi artikel dalam penerbitan Volume 5, No.3 Juni 2021,yaitu:

1. Dr Annisa Utami Seminar (IPB University, Bogor, Indonesia)

2 Prof. Endriatmo Soetarto (IPB University, Bogor, Indonesia)

3 Dr. Rizka Amalia (IPB University, Bogor, Indonesia)

4 Zessy Ardinal, M.Si (IPB University, Bogor, Indonesia)

5 Septri Widiono, M.Si (Universitas Bengkulu, Bengkulu, Indonesia)

6 Dr. Rokhani (Universitas Jember, Jember, Indonesia)

7 Nur Isyana Wianti, M.Si (Universitas Halu Oleo, Kendari, Indonesia)

8 Dr. Ratri Virianita (IPB University, Bogor, Indonesia)

9 Sriwulan Feriandian Falatehan, M.Si (IPB University, Bogor, Indonesia)

Semoga jurnal ini membawa manfaat yang dituju dan menjadi amal kebajikan bagi mereka. 